International Journal of Life Sciences
Available online at www.sciencescholar.us
Vol. 4 No. 1, April 2020, pages: 58-65
e-ISSN: 2550-6986, p-ISSN: 2550-6994
https://doi.org/10.29332/ijls.v4n1.393

\title{
The Properties of Tagua Bark (Brutelephas aequatoriales Spruce) for Producing Traditional Salprieta
}

\author{
Luisana Agustina De La Cruz Zambrano a, Gisselle Yaritza Moreira Espinoza ${ }^{b}$, Stefania Lilibeth \\ Mendoza Meza c, Verónica Dolores Palma Mendoza d
}

Manuscript submitted: 18 November 2019 Manuscript revised: 27 December 2019, Accepted for publication: 30 January 2020

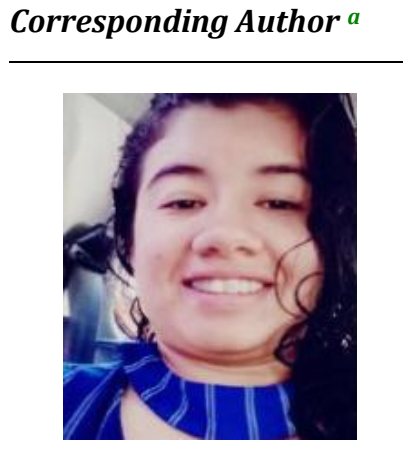

Keywords

bark;

innovation;

splatter;

tagua;

tradition;

\begin{abstract}
Manabí is a province rich in cultural traditions. Its cuisine makes it a province visited by national and foreign tourists. The salprieta is one of the delicacies that identify the province, however the tradition of making salprieta is being lost, that made with tagua that despite not being so widespread became a typical dish of the areas where the crop del Cade constituted the economic support of its inhabitants (Chone, Calceta, Junín, San Plácido, Paján and Jipijapa), because from this plant many by-products are obtained such as the cade used for the construction of roofs of houses and agricultural constructions; the tagua, for the elaboration of crafts, and the bark of this one is used for food of the cattle in the form of flour; and for the elaboration of salprieta in replacement of the corn. The research problem is centered on the loss of ancestral knowledge in the peasant communities to elaborate salprieta using an available resource such as the tagua bark, available raw material that is not used due to ignorance, whose nutritional properties are excellent, as we indicate the tables attached to the document. The objective of this research work is to recover the ancestral knowledge regarding the elaboration of the salprieta using the tagua (Bhytelephas aequatorialis Spruce) as raw material.
\end{abstract}

International Journal of Life Sciences (C) 2020. This is an open access article under the CC BY-NC-ND license (https://creativecommons.org/licenses/by-nc-nd/4.0/).

\section{Contents}

Abstract

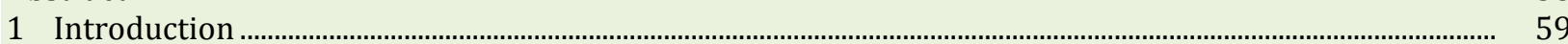

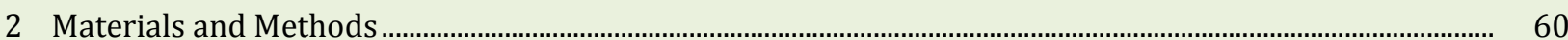

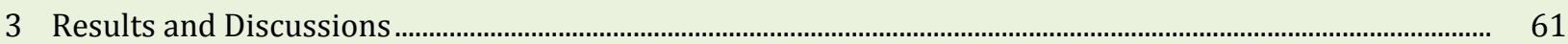

4 Conclusion

\footnotetext{
a Instituto Superior Tecnológico Paulo Emilio Macías, Portoviejo, Manabí, Ecuador

b Instituto Superior Tecnológico Paulo Emilio Macías, Portoviejo, Manabí, Ecuador

c Instituto Superior Tecnológico Paulo Emilio Macías, Portoviejo, Manabí, Ecuador

d Instituto Superior Tecnológico Paulo Emilio Macías, Portoviejo, Manabí, Ecuador
} 


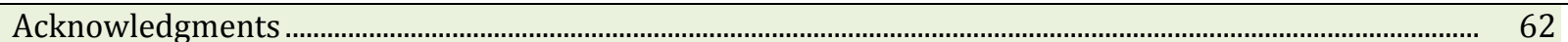

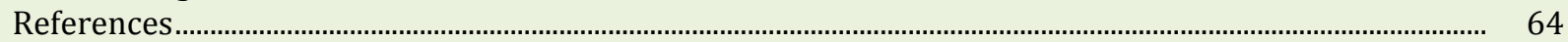



\section{Introduction}

Ecuador is a very rich country, diverse in different products and is also very privileged because thanks to its geographical location it has a similar climate throughout year; which allows the earth to generate the same products during the twelve months of the year. Probably Ecuadorians have become accustomed to this great privilege and do not give it the importance they should. The brown salt is an icon of the Manabita gastronomy, province of the Ecuadorian Coast whose traditional recipe is made with peanut and roasted corn with a refried long onion and achiote. This accompaniment was prepared and consumed only in the countryside, however, at present it can be found in all the houses of the Manabite citizens and in the restaurants of typical food. They serve it with green banana or with ripe roast either for breakfast or as an entrance at lunchtime (Montenegro, 2016).

Manabí has a variety of by-products, among which the tagua stands out, which can be established as a raw material for food (Andrade, 2019). In the areas of the province, where the cultivation of tagua prevails, in addition to countless benefits provided by this plant; it serves as a shed for rural constructions, crafts elaboration. In a tender or mococha state, its water allows the peasant who works long hours in the sun to be hydrated, the bark is used, once roasted for the preparation of the salprieta that being a high carbohydrate food, provides strength to the farmer who consumes it At breakfast. This product has its origin in the preColumbian era and according to Libertad Regalado, a manabita historian, there is no exact date of the origin of Salprieta's production; however, it approximates it to the year 3000 before Christ (Rosero, 2017).

The tagua also is known as cade, mococha, tade, vegetable ivory (English), vegetable ivory, blackhead, cadillo, corozo, vegetable ivory, cob (De la Torre et al., 2008). Phytelephas aequatorialis Spruce is a dioecious palm endemic to western Ecuador. It grows at 1500 meters above sea level on Andean slopes. Large trees can grow to $10 \mathrm{~m}$ high. The infructescence is very large, measuring $30-40 \mathrm{~cm}$ in diameter with a "woody" surface. A single infructescence (see illustration 2) can have seven to twenty-two fruits, each of which contains five to seven seeds. The palm has a brown, rough trunk, formed by the persistent bases of the fallen leaves. The leaves are alternate, pinnate, extended, measuring 6-8 $\mathrm{m}$ long and 0.5-1.0 m wide, with many narrow leaflets arranged in opposite groups. Both male and female flowers are spirally arranged. Palm development can last for 3 years. The seeds are collected after the infructescence matures and falls to the ground, breaking and exposing the seeds.

According to Rea \& Urbano (2017), a plant produces for a period of two to four years and stops doing so for an equal period or does so in smaller quantities. "The tagua, corozo or cade is obtained from the Phytelephasaequatorialis 1 palm, it is native to the humid forests of the Coast and grows from sea level to 1,500 meters in the provinces of Esmeraldas, Santo Domingo, Cotopaxi, Manabí and El Oro. "(Tobar, 2014).

The harvest of Tagua occurs mainly in regions of a subtropical climate, which is why it can be found in countries such as Brazil, Venezuela, Peru, Colombia, Ecuador and Panama; However, it is in Ecuador that it has the widest distribution and socioeconomic use (Vera \& Celi, 2015). In the province of Manabí, where peanuts are traditionally grown, yields are variable, especially because many farmers do not have a fertilization program and also recycle their own planting material. Peanuts are the second most important item in Manabí, with around 6000 hectares. Peanut production in recent years is approximately 28.34 qq (quintals) per ha (Alcívar \& Párraga, 2012).

The high contents of oil, proteins, vitamins, and minerals make peanuts an excellent food source both human and animal, which is why it is widely used in the "snacks', sweets, chocolates and pastry industry (Ayala, 2009). Corn (Zea mays L) belongs to the Gramineae family, it is the most domesticated and evolved plant in the plant kingdom. Originally from the American continent, its cultivation has spread throughout the world. It is used for the manufacture of tortillas, nixtamalized flours, snacks, fermentable beverages, a large number of dishes and for the isolation of starch (Tovar, 2008).

In our town, yellow corn is a crop of great importance, both for human and animal food, because this crop is easy to handle and generates greater profitability compared to other traditional crops such as peanuts.

Zambrano, L. A. D. L. C., Espinoza, G. Y. M., Meza, S. L. M., \& Mendoza, V. D. P. (2020). The properties of tagua bark (brutelephas aequatoriales spruce) for producing traditional salprieta. International Journal of Life Sciences, 4(1), 58-65. https://doi.org/10.29332/ijls.v4n1.393 
(Nole, 2012). According to Cruze (2012), the importance of the splatter in gastronomy is unique and typical in Manabí, tourists who visit the province always like this tasty ancestral preparation, talking about Salprieta is talking about Manabí about its history and of the kitchen of his women, since whoever arrives in Manabi knows that up, to the land of the splashes, peanuts, and corn. These last two products were the basis of stews for ancestral inhabitants throughout the region. While the maize areas of the province are concentrated between Jipijapa, Santa Ana and Rocafuerte, peanut crops were concentrated in Portoviejo. In the valleys of Alajuela and the great savannah of Colón, in the direction of the Santa Ana canton, live the people who inherited the recipe and how to make the salprieta.

According to the Food and cultural heritage of Ecuador (2017), Salprieta is considered in our environment as accompaniment or seasoning. It is one of the main companions of the traditional Manabita food, mostly consumed at breakfast or as a mid-afternoon snack. It is a seasoning made with peanut and corn, yellow and intense flavor. Accompany several dishes such as fish or soups, although the most desired is the roasted banana served with brown salt. For its elaborations are the cornmeal and the peanut roasted separately, in clay pots. It must move constantly so that these ingredients are not burned. Flour the flour together with the peanut and put the mixture in a bowl. Season with salt, pepper and cumin, add the butter and achiote oil and stir well so that all the ingredients are integrated and the mixture becomes an intense yellow color. It is served with roasted or ripe green banana. It is also served separately accompanying other manabitas dishes. Its ingredients provide protein (peanut), corn carbohydrates and fats, although in low amounts.

The brown salt is a very versatile product, it is perfectly complemented in sweet and salty dishes. Among the few users within the gastronomy are Green or ripe roasted with brown salt and patacones, likewise rice is consumed accompanied with brown salt. Although brown salt is also generally used in gastronomic applications only as a garnish, so it is barely used in its entirety (Mera \& Zavala, 2019). The origin of this food is due to the fact that our ancestors had the need to dry their grains since there was no refrigeration or packaging, so they begin to dry these products and grind them since if it wasn't that way their crops were damaged. On the other hand, the salprieta at the beginning was rather used as a condiment to preserve foods such as fish (Tamayo, 2013; Sari et al., 2019).

The research problem is centered on the gradual loss of the ancestral custom of our communities regarding the elaboration of the traditional salprieta using an available resource such as the tagua bark, whose nutritional properties are excellent, as indicated in the attached tables to the document. The objective of the investigation is to recover the ancestral knowledge regarding the elaboration of the salprieta using the tagua (Bhytelephas aequatorialis Spruce) as raw material and innovative component. It has been hypothesized that the use of the tagua bark as a substitute for corn for the preparation of salprieta, has nutritional principles suitable for consumption and that its organoleptic properties are not altered.

\section{Materials and Methods}

Experimental field research was used, since it was tested with tagua as the raw material to obtain splashes of organoleptic characteristics similar to traditional corn-based splashes. Table 1, details all the materials used in the elaboration of the tagua-based splashes.

Table 1

Materials used in the elaboration of the tagua salprieta

\begin{tabular}{lll}
\hline Quantity & Unit & Detail \\
\hline 1 & & Mococha \\
1 & Lb & Peanut \\
1 & & Knife \\
1 & & comal "casserole" \\
1 & & Wooden bat \\
1 & & Windmill \\
1 & & Matte spoon \\
1 & Lb & Corn \\
\hline
\end{tabular}




\begin{tabular}{lll}
\hline 3 & & Garlic \\
1 & Gr & Wood oven \\
15 & & Achiote \\
1 & & Chronometer \\
1 & gr & Gramera \\
10 & Salt \\
\hline \multicolumn{2}{l}{ Source: De La Cruz, L .; Mendoza, S., Moreira, G. and Palma, V. (2019) }
\end{tabular}

To prepare the tagua-based splashes, several mococha heads were collected, which were struck against the floor with wood until the tagua units were obtained. They are placed in a container to immediately remove the bark of the tagua with a knife. When the appropriate amount was obtained, it was roasted on a low heat in a clay pan in a wood oven until it became very crispy. He removed it and allowed it to cool. Once the mixture was cold, grinding was carried out using a hand mill.

The peanut is selected and peeled manually and then roasted and a comal (claypan) was used for roasting the peanut over low heat. At the same time, the corn is roasted over low heat until the toast is at an optimum point. Using a manual mill, all inputs are ground separately. Once the corresponding portions (100gr of tagua bark and 100gr of the peanut) have been measured, we proceed to stir the sample with a wooden spoon until a homogeneous mixture is obtained. Salt, garlic and ground coriander are also placed in the mixture to preserve the traditional flavor of the salprieta.

\section{Results and Discussions}

Bromatological studies were carried out to determine parameters of proteins, fiber, carbohydrates, ashes, humidity, fat, acidity and $\mathrm{Ph}$, both to the salprieta elaborated based on tagua (table 2) and to the traditional salprieta elaborated based on corn (Table 3). Table 2, shows the parameters analyzed in the tagua splatter.

Table 2

Results of the bromatological analysis of the tagua salprieta

\begin{tabular}{llll}
\hline Item & Parameters & Unit & Results \\
\hline 1 & Proteins & $\%$ & 24.05 \\
2 & Fiber & $\%$ & 1.7 \\
3 & Carbohydrates & $\%$ & 14 \\
4 & Ash & $\%$ & 2.87 \\
5 & Humidity & $\%$ & 77.50 \\
6 & Fat & $\%$ & 32,5 \\
7 & Acidity & $\%$ & 0.05 \\
8 & Ph & $\%$ & 7.00 \\
\hline
\end{tabular}

Source: De La Cruz, L .; Mendoza, S., Moreira, G. and Palma, V. (2019)

In table 3, below, the results of analyzes made with corn-based splashes are detailed.

Table 3

Results of the bromatological analysis of the traditional corn-based salprieta

\begin{tabular}{llll}
\hline Item & Parameters & Unit & Results \\
\hline 1 & Proteins & $\%$ & 25.40 \\
2 & Fiber & $\%$ & 1.60 \\
3 & Carbohydrates & $\%$ & 14.2 \\
4 & Ashes & $\%$ & 2.1 \\
5 & Humidity & $\%$ & 70.75 \\
\hline
\end{tabular}

Zambrano, L. A. D. L. C., Espinoza, G. Y. M., Meza, S. L. M., \& Mendoza, V. D. P. (2020). The properties of tagua bark (brutelephas aequatoriales spruce) for producing traditional salprieta. International Journal of Life Sciences, 4(1), 58-65. https://doi.org/10.29332/ijls.v4n1.393 


\begin{tabular}{llll}
\hline 6 & Fat & $\%$ & 33.30 \\
7 & Acidity & $\%$ & 0.06 \\
8 & PH & $\%$ & 5.69 \\
\hline
\end{tabular}

Source: De La Cruz, L .; Mendoza, S., Moreira, G. and Palma, V. (2019)

Comparatively analyzing 200gr samples of tagua splatter and Creole corn splatter in the laboratory, it was obtained that, tagua splatter contributes $24.05 \%$ protein, $32.5 \%$ fat, $14 \%$ carbohydrates and $1.7 \%$ fiber. According to the bromatological study, $\mathrm{Ph}$, approaches the parameters required within the demands for the digestion of a human organism.

In the samples of Creole corn-based splashes, a contribution of $25.40 \%$ protein, content of $33.30 \%$ fat, $14.2 \%$ carbohydrates and $1.60 \%$ fiber was obtained. As for $\mathrm{Ph}$, it significantly moves away from the parameters required within the demands for the digestion of a human organism.

The percentage of ashes obtained in the tagua salprieta sample is higher $(2.87 \%)$ compared to that of the Creole corn-based salprieta, which allows us to know the mineral content of the sample, many of which are of nutritional interest such as calcium and phosphorus and also allows us to know the quality of the product, perhaps because the tagua was exposed to heat for much longer. Regarding the percentage moisture content $(77.50 \%)$ in the tagua splatter in relation to the corn splatter $(70.75 \%)$ it is marked, which implies that there is a decrease in the quality of the product based on tagua and reduce its lifespan.

The conservation status of this relatively abundant species does not involve risk. However, being considered as an economically promising species, a threat would be the destruction of its last wild populations, with the consequent loss of genetic variability (Saltos, 2018). Manabita de calceta gastronomy will have a base similar to manabita gastronomy, however, there are recipes and native techniques that must be researched and documented (Espin, 2016).

According to the publication of Pérez (2004), the nutrient requirement of the human being is influenced by the essentiality and function of the nutrient, by individual differences, environmental factors and by the adaptation to the variable food supply. In the present investigation, nutritional values were obtained from the tagua salprieta, which is constituted in food recommended and accepted by the peasant palates, since the tagua is a product that is available in the rural agricultural estates and is part of perennial crops that contribute to the conservation of the environment. The salprieta has been and is one of the dishes that are part of the diet in the peasant manabitas homes. Its ingredients are easily acquired in the middle by being part of the products that are harvested in the Manabitas gardens.

\section{Conclusion}

Tagua-based salprieta is a food alternative for peasant families who have this crop. Given the scarcity of Creole corn that is the basic input for the preparation of the splatter, the tagua bark is an innovative option as a raw material of the traditional manabita salprieta, preserving the organoleptic characteristics intrinsic to this product icon of the manabita gastronomy. The high percentage of moisture in the splashing, causes the product to suffer a decrease and its storage period is short, so it must be consumed promptly. Also, the production cost of tagua splatter is lower than that of traditional corn-based splatter.

\section{Acknowledgments}

A very special thanks to Ing. Telly Yarita Macías Zambrano, our beloved career teacher and unconditional friend, who has been able to motivate and guide us on the path of research, and lead us to an Institutional Recognition in the III CREA INGENIOS 2019 ITSPEM Contest.

To our dear parents for their love and dedication, in our studies, in our lives.

To the Licensed. Lourdes Santamaría, mother at heart, guide and total support in our academic training and in our lives.

To our beloved tutor of the research work, for her dedication, support and successful guidance in this work, demonstrating her unconditional support throughout the research process. 
To the authorities of our Institution, Lcda. Blanca Celina Meza Cruz, Mgs. and Ing. Gregorio Mendoza Cedeño, Rector and Academic Vice-Chancellor, for the Recognition that we receive from his part with the III place in the Ancestral Knowledge + Innovation component of the III CREA INGENIOS 2019 Contest, as well as when establishing the graduation modality with the publication of the scientific article.

To the editorial group of the IJLS Magazine for considering this research work for publication, so that this ancestral knowledge of our Montuvia manabita culture is not lost, on the contrary, it reaches the knowledge of many people across the planet.

Zambrano, L. A. D. L. C., Espinoza, G. Y. M., Meza, S. L. M., \& Mendoza, V. D. P. (2020). The properties of tagua bark (brutelephas aequatoriales spruce) for producing traditional salprieta. International Journal of Life Sciences, 4(1), 58-65. https://doi.org/10.29332/ijls.v4n1.393 


\section{References}

Alcívar, E. and Párraga, F. (2012). Effect of biol enriched with acid-lactic bacteria on the productivity of peanut cultivation (Arachis hypogaea L.). Calceta: Manabí Agricultural Polytechnic High School (ESPAM).

Andrade, J. (2019). Inclusion of tagua rsiduos flour (Phytelephas aequatorialis) in the COBB 500 chicken diet. Calceta: Higher Agricultural Polytechnic School of Manabí ESPAM.

Ayala, TC (2009). Feasibility study for the production and commercialization of peanuts (Arachis hypogaea L) in the canton hipijapa, province of Manabi. Quito: San Francisco University of Quito.

Cruze, L., Kohno, S., McCoy, M. W., \& Guillette Jr, L. J. (2012). Towards an understanding of the evolution of the chorioallantoic placenta: steroid biosynthesis and steroid hormone signaling in the chorioallantoic membrane of an oviparous reptile. Biology of reproduction, 87(3), 71-1. https://doi.org/10.1095/biolreprod.112.101360

De la Torre, J. R., Walker, C. B., Ingalls, A. E., Könneke, M., \& Stahl, D. A. (2008). Cultivation of a thermophilic ammonia oxidizing archaeon synthesizing crenarchaeol. Environmental microbiology, 10(3), 810-818. https://doi.org/10.1111/j.1462-2920.2007.01506.x

Espin, A. (2016). Study of the gastronomic heritage of the city of Calceta in the province of Manabí. Calceta: School of Gastronomy, Polytechnic Agricultural School of Manabí (ESPAM).

Food and cultural heritage of Ecuador. (August 20,2017). Food and cultural heritage.

Mera, S.H., \& Zavala, E. (2019). Technical feasibility analysis for the production of sausage with Oca (Oxalis Tuberosa). Guayaquil: University of Guayaquil.

Montenegro, E. (2016). Traditional Ecuadorian cuisine. Quito: San Francisco University of Quito.

Nole, P. (2012). Agronomic evaluation of 8 experimental hybrids versus 3 commercial corn hybrids. Loja: National University of Loja.

Pérez, J. (2004). Nutrient quality in human food. Cuban Journal of Biomedical Research v.23 n.4, 1-14.

Rea, I., \& Urbano, R. (2017). Development of a cream with exfoliating characteristics based on the powder coming from the tagua. Quito: Central University of Ecuador.

Rosero, S. (2017). Feasibility study of production and marketing of tagua. Guayaquil: Santiago de Guayaquil Catholic University.

Saltos, E. (2018). Use and potential of the use of E Phytelephas aequatorialis Spruce as a non-timber forest product. Jipijapa: State University of the South of Manabi - UNESUM.

Sari, P. R. J., Wisudawati, N. N. S., \& Yulianti, N. M. D. R. (2019). Selfie tourism promotion to support innovative tourism in the era of disruption. International Research Journal of Management, IT and Social Sciences, 6(6), 172-177. https://doi.org/10.21744/irjmis.v6n6.789

Tamayo, G. (2013). Culture, Mountain, Sea and Gastronomy "(Manabi Provincial Government). QUITO: SAN FRANCISCO DE QUITO UNIVERSITY.

Tovar, T. (2008). Morphological and thermal characterization of corn starch (Zea mays L) obtained by different isolation methods. Pachuca de Soto, Hidalgo: Autonomous University of the State of Hidalgo.

Vera, K., \& Celi, K. (2015). Jewelry export plan based on Tagua. Guayaquil: Salesian Polytechnic University Ecuador. 


\section{Biography of Authors}



Zambrano, L. A. D. L. C., Espinoza, G. Y. M., Meza, S. L. M., \& Mendoza, V. D. P. (2020). The properties of tagua bark (brutelephas aequatoriales spruce) for producing traditional salprieta. International Journal of Life Sciences, 4(1), 58-65. https://doi.org/10.29332/ijls.v4n1.393 